\title{
PROCESS FOR INTELLIGIBILITY EVALUATION OF TRANSMISSION OF THE SLOVAK SIGN LANGUAGE IN E-LEARNING HEARING IMPAIRED PEOPLE
}

Jana FILANOVÁ*, Ekonomická univerzita v Bratislave

Přijato: 7. 7. 2015 / Akceptováno: 26. 10. 2015

Typ článku: Výzkumný článek

DOI: $10.5507 /$ jtie.2015.018

Abstract: The article deals with the use of videoconferencing in support of elearning hearing impaired people. The combination of audio and image information serves for understanding the content of lectures or presentations in the form of videoconferencing. This does not apply for the hearing impaired people, who are only dependent on quality transmission of moving images, especially in a defined area of sign language. The contribution describes the proposal of evaluation process sentential intelligibility, which we can determine at what degradation of moving picture is a video sequence of sentences understood for deaf people yet.

Key words: e-learning, videoconferencing, hearing disability, process modeling.

\section{PROCES HODNOTENIA ZROZUMITELNOSTI PRENOSU SLOVENSKÉHO POSUNKOVÉHO JAZYKA V E-VZDELÁVANÍ SLUCHOVO POSTIHNUTÝCH}

Resumé: Článok sa zaoberá využitím videokonferencie na podporu e-vzdelávania sluchovo postihnutých. Na pochopenie obsahu prednášky, či prezentácie vo forme videokonferencie slúži kombinácia zvukovej aj obrazovej informácie. To neplatí pre sluchovo postihnutých občanov, ktorí sú odkázaní len na kvalitný prenos pohyblivého obrazu, a to hlavne $v$ definovanom priestore znakového jazyka. Príspevok predstavuje návrh procesu hodnotenia vetnej zrozumitelnosti, pomocou ktorého môžeme zistit', pri akej degradácii pohyblivého obrazu je video sekvencia naposunkovanej vety pre nepočujúceho ešte zrozumitel’ná.

Klíčová slova: e-vzdelávanie, videokonferencia, sluchové postihnutie, modelovanie procesov.

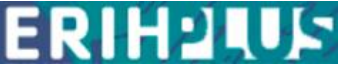

*Autor pro korespondenci: jana.filanova@euba.sk
This journal was approved on 2015-04-23 according to ERIH PLUS criteria for inclusion. 


\section{1 Úvod}

Všeobecná deklarácia l'udských práv OSN i Deklarácia základných práv mentálne postihnutých $\mathrm{s}$ aplikáciou na všetkých invalidných l’udí OSN zdôrazňujú aj právo na vzdelanie a získavanie informácií prostredníctvom sprístupnenia prostredia, bezbariérovosti a opatrení na stály prístup $\mathrm{k}$ informačným zdrojom a l'ahšie dorozumenie sa. Jedným z možných riešení tohto problému je práve sprístupnenie video telefónie a videokonferencie l'ud'om s rôznou formou postihnutia (Filanová, 2011).

Jednou z kategórii postihnutých l'udí, pre ktorú znamená využitie videokonferencie obrovský skok vpred, sú práve sluchovo postihnutí. Komunikácia sluchovo postihnutých sa od komunikácie počujúcich odlišuje predovšetkým pohybmi rúk a mimických svalov, taktiež ešte zmenou polohy hlavy a hornej časti trupu. Pre sluchovo postihnutých je osvojenie či uchovanie schopnosti komunikovat' orálnym spôsobom vel'mi tažké. Závisí to aj od typu poruchy sluchu v závislosti od postihnutia sluchového aparátu (Tomasco, 2010).

Skupiny s percepčnou poruchou a koritikálnym postihnutím sluchových funkcií využívajú na komunikáciu posunkový jazyk. Je to pre nich najprirodzenejšia forma komunikácie a preto je pre nich využívanie videokonferencií optimálnym spôsobom komunikácie a vzdelávania sa „na dial'ku“.

V súčasnosti sa sluchovo postihnutí na Slovensku majú možnost' vzdelávat' po úroveň stredných škôl, a to na špeciálnych odborných učilištiach v Bratislave, Kremnici, Prešove a Lučenci, na ktorých prevláda príprava nepočujúcich na výkon pracovných pozícií $\mathrm{s}$ prevahou fyzickej činnosti.

Európska kultúrna spoločnost' (EKS) a Slovenský zväz sluchovo postihnutých (SZPB) už niekol'ko rokov spolupracujú na projektoch, ktoré sú zamerané na vzdelávanie sluchovo postihnutých a ich lepšie začlenenie do pracovného života. Jedným z ciel'ov ich spoločného projektu je zvyšovanie digitálnej gramotnosti sluchovo postihnutých formou kombinovaného vzdelávania, ktoré využíva e-learning.

Úspech e-vzdelávania vel'mi závisí od schopnosti využívat' a kombinovat' najvhodnejšie a najl'ahšie dostupné metódy a prístupy tak, aby bola oslovená čo najširšia skupina študentov a pritom boli využité ich schopnosti, možnosti a požiadavky. U nepočujúcich sú tieto schopnosti a možnosti obmedzené a jednou z ich hlavných požiadaviek je využitie slovenského posunkového jazyka a odčíania z pier pri evzdelávaní. Jednou zo súčastí e-vzdelávania pre sluchovo postihnutých je prístup $\mathrm{k}$ databáze prednášok a prezentácií $\mathrm{v}$ posunkovom jazyku vo forme videozáznamu. Druhou súčast’ou je možnost' zúčastnit' sa prednášok a prezentácíi $v$ reálnom čase prostredníctvom videokonferencie.

$\mathrm{Na}$ pochopenie obsahu prezentácie vo forme videokonferencie slúži kombinácia zvukovej aj obrazovej informácie. To neplatí pre sluchovo postihnutých občanov, ktorí sú odkázaní len na kvalitný prenos pohyblivého obrazu, a to hlavne v definovanom priestore znakového jazyka.

\section{Použité výskumné metódy}

Posunkový jazyk sa od hovoreného jazyka odlišuje hlavne typom komunikačného kanála. Hovorený jazyk sa vníma sluchom a produkuje slovami a posunkový jazyk sa vníma zrakom a produkuje posunkami. Inými slovami, na rozdiel od hovoreného jazyka, ktorý využíva audio-orálny kanál, sa komunikácia nepočujúcich odohráva primárne vo vizuálno-motorickom kanáli (Vojtechovský \& Holubová, 2009). 
Pri produkcii posunkového jazyka sa využíva trojrozmerný priestor - posunkový priestor, ktorý je ohraničený zhruba rozpaženými laktami, temenom hlavy a pásom, ako je znázornené na obrázku 1 . Takže pri videokonferencii je vel'mi dôležité, aby nepočujúci videl celý tento priestor, aby mohol správne pochopit' podstatu prezentácie.

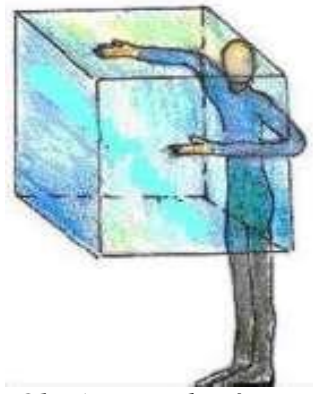

Obr 1: Posunkový priestor

Tak, ako v akustike (Makáň, 1995), aj pri posunkovom jazyku môžeme skúmat' dva typy zrozumitel'nosti a to hláskovú a vetnú. Hláskovú samozrejme len v prenesenom slova zmysle, ked'že u sluchovo postihnutých ide skôr o znakovú zrozumitel'nost'.

V našom výskume sme sa zaoberali vetnou zrozumitel'nost'ou. Hlavným ciel'om nášho výskumu bolo navrhnút' a otestovat' proces hodnotenia vetnej zrozumitel'nosti, pomocou ktorého môžeme zistit', pri akej degradácii pohyblivého obrazu je video sekvencia naposunkovanej vety pre nepočujúceho ešte zrozumitel’ná, respektíve ako musí respondent prispôsobit' rýchlost' svojho posunkovania, aby pri danom rozlíšení obrazu bolo jeho posunkovanie pre druhú stranu zrozumitel’né. Testovanie vetnej zrozumitel'nosti je závislé od dvoch základných kritérií, a to zrozumitel'nosti podl’a premenlivej prenosovej kapacity kanála a zároveň od rýchlosti posunkovania.

Návrh procesu hodnotenia vetnej zrozumitel'nosti pozostáva z piatich základných postupných krokov, ktoré sú zobrazené na obrázku 2.:

1. Proces nahrávania video sekvencií

2. Tvorba testovacích sekvencií

3. Výber sekvencií pre respondentov

4. Proces testovania

5. Proces spracovania výsledkov

Prvým dôležitým krokom pri testovaní vetnej zrozumitel'nosti je proces nahrávania referenčných video sekvencií. Za referenčné video sekvencie považujeme sekvencie s najvyššou kvalitou obrazu (napr. podl'a odporúčania H.264), preto je potrebné prispôsobit' tomu nie len celú prípravu nahrávania, ale aj vhodný výber kvalitnej kamery (Morris \& Elshehry, 2002). Video sekvencia by nemala presiahnut maximálny čas 50 sekúnd, aby bol respondent schopný vetu zachytit' a následne ju prepísat' (Richardson, 2010).

Proces tvorby testovacích sekvencií pozostáva z d’alších podprocesov (obrázok 2). Najprv sú vety $z$ referenčných video sekvencií nahraté ešte raz pomocou pomalého a zrýchleného posunkovania. $\mathrm{V}$ d’alšom kroku sú video sekvencie degradované kódovaním 
s rôznou bitovou rýchlost'ou. Pri tomto degradovaní a následnom testovaní môžeme nastavit' hranicu zrozumitel'nosti. To znamená, že určíme, pri akom zhoršení kvality video sekvencie (znížení prenosovej kapacity kanála), je naposunkovaná veta ešte zrozumitel’ná.

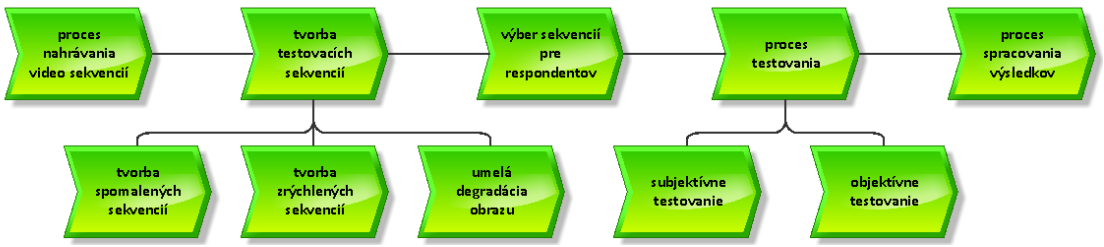

Obr 2: Návrh procesu hodnotenia vetnej zrozumitelnosti

Je dôležité, aby respondent dostal na testovanie také sekvencie, aby si na základe predchádzajúcej nemohol domysliet' význam nasledujúcej. Zist’ovanie vetnej konštrukcie prebieha tak, že testujúci si pustí video sekvenciu, ktorá obsahuje jednu vetu v slovenskom posunkovom jazyku. Respondenti hodnotia kvalitu každej sekvencie ihned' po jej prezentácii. Táto metóda testovania kvality sekvencií bola navrhnutá podl'a vzoru metódy ACR (Absolute Category Rating - úplné kategorické hodnotenie) (Winkler, 2005). Na hodnotenie zrozumitel'nosti jednotlivých ukážok boli navrhnuté body hodnotenia znázornené v tabul'ke 1 . Testovaný subjekt na základe subjektívneho pocitu zakrúžkuje odpoved', čo predstavuje prvý krok testovania. Pri tejto odpovedi zohráva úlohu celkový pocit testovaného, akým dojmom naňho vplýva video sekvencia.

\begin{tabular}{|r|l|}
\hline body & \multicolumn{1}{|c|}{ vetná zrozumitel'nost' } \\
\hline 1 & Úplne zrozumitel'né \\
\hline 2 & Čiastočne zrozumitel'né, pochopená podstata vety \\
\hline 3 & Čiastočne zrozumitel'né, ale nepochopená podstata vety \\
\hline 4 & Nezrozumitel'né \\
\hline
\end{tabular}

Tab 1: Bodové hodnotenie vetnej zrozumitelnosti

V druhej časti testu prepíše respondent vetu, ktorú uvidí v posunkovom jazyku, do písomnej formy v slovenskom jazyku. Urobí to hned’ po zakrúžkovaní určitého bodu hodnotenia.

Proces spracovania výsledkov spočíva $\mathrm{v}$ tom, že nezávislý subjekt porovná vetu napísanú respondentom $\mathrm{s}$ referenčnou vetou a ohodnotí ju tiež podl’a navrhnutej tabul'ky na hodnotenie zrozumitel'nosti. Bodom jeden „Úplne zrozumitel'né“ ohodnotí vetu vtedy, ak testovaný preložil každé slovo z vety a celkovo je táto veta významovo správne. Druhým bodom „Čiastočne zrozumitelné, ale pochopená podstata“ označí vetu vtedy, ak testujúci nezachytil všetky slová, respektíve im nerozumel, ale podstata vety je významovo zachytená správne. Bodom tri „Čiastočne zrozumitel'né, ale nepochopená podstata“ ohodnotí vetu, ak niektoré slová vo vete sú pochopené správne, no nie je medzi nimi súvislost', čiže podstata je v celku nepochopená. A nakoniec bod štyri „Nezrozumitel'né“ je určený pre taký prepis vety, kde testovaný subjekt napíše minimum správne prepísaných slov a veta nie je vôbec významovo správne. Následne je možné porovnat' výsledky testujúceho (subjektívne hodnotenie) a hodnotiaceho subjektu (objektívne hodnotenie). Podla vyhodnotených výsledkov je možné určit', pri akom zhoršení video sekvencie je ešte 
podstata zrozumitel'ná, respektíve ako je nutné upravit' posunkovanie, aby bola daná video sekvencia zrozumitel'ná aj pri značnom zhoršení obrazu (Polec, Ondrušová, Mordelová \& Filanová, 2010).

\section{Priebeh výskumu}

V rámci procesu nahrávania video sekvencí́ boli nahraté dve video sekvencie, ktoré sme definovali ako východiskové s najvyššou kvalitou obrazu. V prvej referenčnej video sekvencii bol nasnímaný muž a obsahom sekvencie bola veta v slovanskom posunkovom jazyku s nasledujúcim textom: „Vítam Vás. Rád by som Vás informoval o aktivite Foto maratón nepočujúcich. Je to výhradne pre nepočujúcich, nie pre počujúcich. Ak sa chcete prihlásit', vstupný poplatok je 5 Eur.“ Ukážka prvej referenčnej video sekvencie je znázornená na obrázku 3.

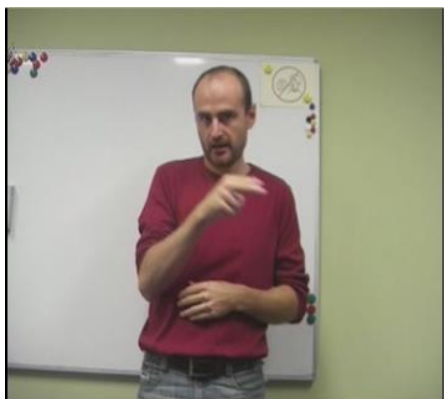

Obr 3: Ukážka prvej referenčnej video sekvencie naposunkovanej mužom

V slovenskom jazyku sa vybratý text skladá zo štyroch viet. V slovenskom posunkovom jazyku je to akoby jedna veta, kde za sebou posunkujúci heslovite vyjadruje základné informácie. Pre porovnanie veta v slovenskom jazyku sa skladá z 29 slov, pričom $\mathrm{v}$ slovenskom posunkovom jazyku $\mathrm{v}$ tomto konkrétnom prípade nepočujúcemu stačilo 17 posunkov na vyjadrenie tej istej podstaty.

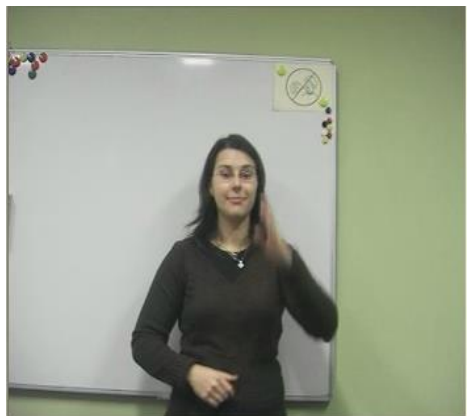

Obr 4: Ukážka druhej referenčnej video sekvencie naposunkovanej ženou 
V druhej referenčnej video sekvencii bola nasnímaná žena a obsahom sekvencie bola veta v slovanskom posunkovom jazyku s nasledujúcim textom: „Ahoj. Každoročne sa koná festival k Medzinárodnému dňu nepočujúcich. Minulý rok sa konal v Lučenci a tento rok sa bude konat' v Bratislave. “ Ukážka druhej referenčnej video sekvencie je znázornená na obrázku 4. V slovenskom jazyku text obsahuje 23 slov, čo je v posunkovom jazyku vyjadrené 13 -timi posunkami.

Proces tvorby spomalených a zrýchlených sekvencií spočíval v tom, že okrem referenčnej sekvencie, ktorá bola nahratá ako sekvencia posunkového jazyka normálnou rýchlost'ou posunkovania, bola ešte nahratá presne tá istá veta pomocou rýchlejšieho posunkovania a vd’alšom kroku pomocou posunkovania $\mathrm{v}$ spomalenom tempe. $\mathrm{Na}$ základe toho môžeme vyhodnotit', či má význam pri zhoršenej kvalite obrazu úprava rýchlosti posunkovania na určitú rýchlost', pri ktorej by bol kontext naposunkovanej vety pre prijímajúcu stranu zrozumitel’nejší.

V rámci podprocesu umelej degradácie obrazu boli všetky video sekvencie degradované kódovaním s rôznou bitovou rýchlost'ou prostredníctvom programu VcDemo. VcDemo je zdarma poskytovaný softvér pre Windows, ktorý umožňuje interaktívnu kompresiu obrazu a videa. Nastavovaním kvantizačného parametra od 1 po 51 bola menená prenosová rýchlost' jednotlivých sekvencií. Výraznejšie zhoršenie kvality video sekvencií sa prejavilo až od nastavenia kvantizačného parametra $Q$ na hodnotu 30, čiže v kroku, ked' prenosová rýchlost' klesla pod $200 \mathrm{kbit} / \mathrm{s}$ a priemerný odstup signál šum klesol pod $40 \mathrm{~dB}$. $Z$ toho dôvodu boli na testovanie použité len sekvencie degradované kvantizačným parametrom od 30 do 50.

Ukážka video sekvencie degradovanej kvantizačným parametrom $Q=50$ je znázornená na obrázku 5.

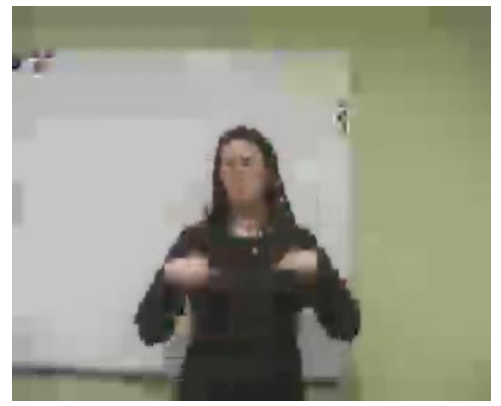

Obr 5: Ukážka degradovanej video sekvencie

Testovanie prebehlo na skupine s počtom testujúcich 60 (počet testujúcich bol obmedzený znalost’ou slovenského posunkového jazyka). Pri výber a počte testovaných sekvencií bolo dôležité zabezpečit', aby si testujúci nemohol domysliet' podstatu prezentovaného videa $\mathrm{z}$ predchádzajúcej testovanej sekvencie, takže jeden respondent testoval len dve a to rozdielne video sekvencie s rôznou hodnotou degradácie.

Proces testovania prebiehal nasledovne: Respondentovi bola prehratá jedna $\mathrm{z}$ video sekvencií určených na testovanie. Respondent označil $\mathrm{v}$ hodnotiacom hárku jeden $\mathrm{z}$ bodov zrozumitel'nosti podl'a tabul'ky 1 . Tento krok bol súčast'ou subjektívneho hodnotenia. Na účely objektívneho hodnotenia zrozumitel'nosti prepísal respondent vetu do slovenského 
jazyka. Táto veta bola porovnaná s referenčnou vetou a následne ohodnotená taktiež podl’a navrhnutej tabul'ky na hodnotenie zrozumitel'nosti (tabul'ka 1). Testovanie prebehlo na jednom počítači na zabezpečenie rovnakých podmienok pre všetkých testujúcich.

\section{Výsledky výskumu}

Ciel'om nášho výskumu bolo navrhnút' a otestovat' proces hodnotenia vetnej zrozumitel'nosti, pomocou ktorého môžeme zistit', pri akej degradácii pohyblivého obrazu je video sekvencia naposunkovanej vety pre nepočujúceho ešte zrozumitelná, respektíve ako musí respondent prispôsobit' rýchlost' svojho posunkovania, aby pri danom rozlíšení obrazu bolo jeho posunkovanie pre druhú stranu zrozumitel'né. Na dosiahnutie hlavného ciel'a bolo potrebné vyhodnotit' percentuálnu zhodu subjektívneho a objektívneho testovania (tabul'ka 2).

\begin{tabular}{|c|c|c|}
\cline { 2 - 3 } \multicolumn{1}{c|}{} & muž & žena \\
\hline pomalé posunkovanie & $69,2 \%$ & $81,8 \%$ \\
\hline normálne posunkovanie & $70,0 \%$ & $81,8 \%$ \\
\hline rýchle posunkovanie & $84,6 \%$ & $72,7 \%$ \\
\hline
\end{tabular}

Tab 2: Percentuálna zhoda subjektivneho a objektivneho testovania

Na základe výsledkov môžeme konštatovat', že subjektívne (1. krok testovania) a objektívne hodnotenie (2. krok testovania) je minimálne v 70\%-tách odpovedí zhodné. Väčšiu výpovednú hodnotu pri d’alšom spracovaní majú výsledky objektívneho hodnotenia, no pri zhode viac ako 70 \% môžeme brat do úvahy aj výsledky subjektívneho testovania.

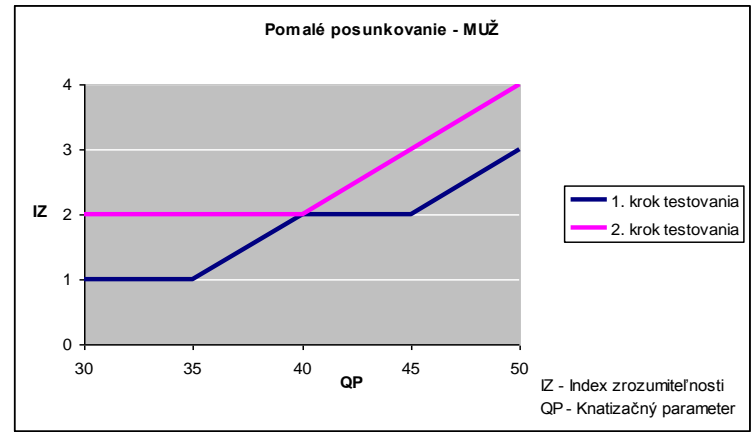

Graf 6: Závislost' indexu zrozumitelnosti IZ od kvantizačného parametra QP

Na grafe 6 je ukážka spracovania výsledkov závislosti indexu zrozumitel'nosti IZ od kvantizačného parametra QP pre pomalé posunkovanie u muža. Na grafe 6 vidíme, že hranica zrozumitel'nosti pre subjektívne hodnotenie (1. krok testovania) sa pohybuje okolo hodnoty $\mathrm{QP}=50$ a pre objektívne hodnotenie (2.krok testovania) sa pohybuje okolo hodnoty $\mathrm{QP}=45$.

Podobne boli spracované aj výsledky hranice zrozumitel’nosti v závislosti od prenosovej rýchlosti. Pre väčšiu zrozumitel'nost' boli celkové výsledky spracované do tabul'ky (tabul'ka 3). 


\begin{tabular}{|c|c|c|c|}
\hline \multicolumn{3}{|c|}{ Posun hranice zrozumitel'nosti } \\
\hline \multirow{2}{*}{\multicolumn{2}{|c|}{$v$ video sekvencia }} & \multicolumn{2}{|c|}{ Hranica zrozumitel'nosti } \\
\cline { 3 - 4 } & & QP & Prenosová rýchlost' [kbit/s] \\
\hline \multirow{3}{*}{ MUŽ } & pomalé posunkovanie & 40 & 30 \\
\cline { 2 - 4 } & normálne posunkovanie & 45 & 20 \\
\cline { 2 - 4 } & rýchle posunkovanie & 43 & 50 \\
\hline \multirow{3}{*}{ ŽENA } & pomalé posunkovanie & 48 & 20 \\
\cline { 2 - 4 } & normálne posunkovanie & 40 & 25 \\
\cline { 2 - 4 } & rýchle posunkovanie & 40 & 25 \\
\hline
\end{tabular}

Tab 3: Výsledky pre posun hranice zrozumitel'nosti

V d’alšej časti procesu spracovania výsledkov sme zistovali, či môže rýchlost' posunkovania $\mathrm{v}$ značnej miere prispiet' $\mathrm{k}$ posunu hranice zrozumitel'nosti. Na toto porovnanie boli použité už len výsledky z objektívneho hodnotenia, ktoré majú väčšiu výpovednú hodnotu.

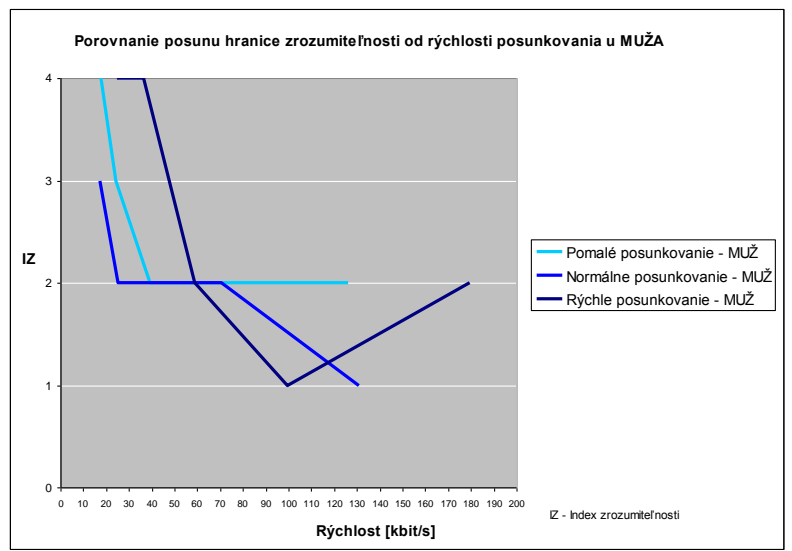

Graf 7: Závislost' indexu zrozumitel'nosti IZ od rýchlosti posunkovania

Z grafu 7 vidiet', že hranica zrozumitel'nosti sa vyskytuje pri hodnote prenosovej rýchlosti $60 \mathrm{kbit} / \mathrm{s}$ pre rýchle posunkovanie a okolo $30 \mathrm{kbit} / \mathrm{s}$ pre normálne a pomalé posunkovanie u muža. Grafické znázornenie jasne ukazuje, že tento posun nie je až taký vel'ký ako sme na začiatku výskumu očakávali, ale platí, že pri značnom zhoršení obrazu musíme spomalit' posunkovanie, aby bola zrozumitel’nost' väčšia.

\section{Diskusia}

Zo spracovaných výsledkov je zrejmé, že zrozumitel'nost' slovenského posunkového jazyka je závislá na kvalite obrazu, ale nie až v takej miere ako sme predpokladali. V priemere stačí zabezpečit' pri prenose prezentácie prenosovú rýchlost' minimálne 70 
kbit/s na to, aby nepočujúci zachytil podstatu posunkovaného jazyka. Ovel’a dôležitejšie je však zabezpečit' kvalitnú web kameru, jej dobré nastavenie na posunkujúceho a vel'kú úlohu zohráva aj dobré nasvietenie posunkujúceho. Ďalšie parametre ovplyvňujúce zrozumitel'nost' sa vzt'ahujú na samotné posunkovanie, ktoré by malo byt' výrazné a mal by byt' využitý celý posunkový priestor, nie len jeho čast'.

Kritériá hodnotenia kvality videokonferencie sú úzko prepojené s kódovaním a kompresiou, pretože sú prostriedkom pre určenie hranice, nakol'ko je možné znižovat' vel'kost' dátového toku videa. Tieto kritériá však nezohl'adňujú potrebu zrozumitel'nosti posunkov, znakov alebo gest. Neexistuje žiadne odporúčanie ITU (International Telecommunication Union) pre hodnotenie kvality a zrozumitel'nosti videa obsahujúceho alternatívne a augmentatívne spôsoby komunikácie (Heribanová, P., Polec, J., Ondrušová, S. \& Host'ovecký, M., 2011).

Výskum zaoberajúci sa vetnou zrozumitel'nost’ou znakovej reči je na Slovensku ojedinelý, no výsledky nášho výskumu môžeme porovnat' s výsledkami výskumu zaoberajúceho sa zrozumitel'nostou prenosu „logatómov“ a znakov prstovej abecedy. Podobne, ako v našom výskume, bola na základe výsledkov objektívneho hodnotenia zrozumitel'nosti navrhnutá metóda, ktorá by najlepšie korelovala so zrozumitel'nostou, a teda by mohla predstavovat' metódu na automatické hodnotenie zrozumitel'nosti videa $\mathrm{s}$ posunkovou rečou a prstovou abecedou (Heribanová, P., Polec, J. \& Krulikovská, L., 2011).

Na rozdiel od Slovenska, výskum v zahraničí už vedie ku konkrétnym projektom, ktoré sa zaoberajú pomocou sluchovo postihnutým v podobe rôznych rozpoznávačov a prekladačov znakovej reči. Napríklad spoločnost' IBM vyvinula dômyselný systém nazvaný SiSi (Say It Sign It), ktorá automaticky prekladá hovorené slovo do britského posunkového jazyka (BSL), ktorý je potom zobrazovaný animovanými digitálnymi znakmi alebo avatarom (Tomasco, S., 2010).

Japonskí nepočujúci používajú na komunikáciu japonskú znakovú reč (JSL - Japanese sign language), ktorá je foneticky rozdielna od japonského jazyka. Japonskí vedci úspešne predviedli prototyp prekladového systému nazvaný SYUWAN, ktorý prekladá z japonskej znakovej reči do japončiny (Tokuda, M. \& Okumura, M., 2010).

\section{Záver}

V príspevku je predstavený návrh procesu hodnotenia vetnej zrozumitel'nosti, pomocou ktorého môžeme zistit', pri akej degradácii pohyblivého obrazu je video sekvencia naposunkovanej vety pre nepočujúceho ešte zrozumitel'ná. Proces hodnotenia vetnej zrozumitel'nosti pozostáva $\mathrm{z}$ piatich podprocesov, ktoré sú $\mathrm{v}$ článku podrobne rozobrané a podložené príkladom.

Na základe navrhnutého procesu hodnotenia vetnej zrozumitel'nosti bola vypracovaná metóda, ktorú môžeme d’alej využit' na hodnotenie vetnej zrozumitel'nosti prenosu prezentácie $\mathrm{v}$ slovenskom posunkovom jazyku prostredníctvom videokonferencie. Metóda vychádza zo subjektívnej metódy ACR, ktorá je prispôsobená pre hodnotenie kvality videokonferencie pre sluchovo postihnutých. Je to subjektívna metóda, kde ihned' po prezentácií sekvencie nastáva hodnotenie jej kvality respondentom. Priebeh testovania závisí nie len od kvalitnej prípravy video sekvencií a samotných testov, ale aj od výberu vhodnej vzorky respondentov z radov sluchovo postihnutých občanov. 
Táto práca bola podporená Vedeckou agentúrou VEGA prostredníctvom finančnej podpory projektu č. 1/0336/14.

\section{Literatúra}

Filanová, J. (2011) Nová metóda na hodnotenie kvality videokonferencie v e-vzdelávaní sluchovo postihnutých. Inovačný proces v e-learningu: recenzovaný zborník príspevkov z medzinárodnej vedeckej konferencie, Bratislava, 10. marec 2011. Vydavatel'stvo EKONÓM.

Heribanová, P., Polec, J., Ondrušová, S. \& Host'ovecký, M. (2011) Intelligibility of Cued Speech on Video. In: World Academy of Science, Engineering and Technology

Heribanová, P., Polec, J. \& Krulikovská, L. (2011) Logatom Intelligibility of

Single-Handed Finger Alphabet. In: Proceedings ELMAR-2011 : 53rd International Symposium ELMAR-2011,14-16 September 2011, Zadar, Croatia. - Zadar : Croatian Society Electronics in Marine

Makáň, F. (1995) Elektroakustika. Vydavatel'stvo STU Bratislava

Morris, T. \& Elshehry, O. S. (2002) Hand segmentation from live video. In The 2002 Intl. Conference on Imaging Science, Systems and Technology, UMIST, Manchester, UK.

Občianske združenie Európska kultúrna spoločnost', Dostupné z: http://www.eiria.eu/ Polec, J., Ondrušová, S., Mordelová, A. \& Filanová, J. (2010) New Objective Method of Evaluation Cued Speech Recognition in Videoconferences. In: Proceeding Redžurr, 4th International Workshop on Speech and Signal Processing. Bratislava, Slovak Republic.

Richardson, I. E. G. (2010) H.264 and MPEG-4 Video Compression, Video Coding for Next-generation Multimedia. John Wiley \& Sons Ltd.

Tokuda, M. \& Okumura, M. (2010) Automatic Translation from Japanese into Japanese Sign Language.

Dostupné z: http://www.springerlink.com/content/mc9wxaxjd37yabur/fulltext.pdf Tomasco, S. (2010) IBM Research Demonstrates Innovative 'Speech to Sign Language' Translation System (online). [cit. 2015-06-25]. Dostupné z: http://www03.ibm.com/press/us/en/pressrelease/22316.wss

Vojtechovský, R. \& Holubová, V. (2009) Nepriame pomenovania v slovenskom posunkovom jazyku. SPENEDA.

Winkler, S. (2005) Digital video quality vision model and metrics, Chichester: John Wiley $\&$ Sons Ltd. 